\title{
EVALUATION OF THE RESULTS OF THE EUROPEAN INVESTIGATION ORDER*
}

\author{
Željko Karas, PhD, Associate Professor \\ Police College in Zagreb \\ Avenija Gojka Šuška 1, Zagreb, Croatia \\ zkaras@fkz.hr
}

\author{
Silvija Pejaković Đipić, LLM, Teaching Assistant \\ Police College in Zagreb \\ Avenija Gojka Šuška 1, Zagreb, Croatia \\ pdjipic@fkz.hr
}

\begin{abstract}
Authors are researching development and analyzing first effects of cross-border investigative measures, following enactment of the European Investigation Order (EIO). The EIO extends number of investigative actions which can be requested from other countries, and simplifies the process of evidence transfer. The paper is discussing problems during development of the EIO, its' reception in Croatian system and a case study of the first orders received in Croatian police in 2018 is performed.

This instrument is not imposing common legislative standards, but introducing the principle of mutual recognition which is derived from other law fields. The main risk is that diversity of some investigative measures could lead to the inadmissibility of evidence in subsequent criminal procedure. Results are showing that there hadn't been obstacles in police practice so far. Main issues on principle of mutual recognition, double criminality or admissibility of evidence were not manifested in case study, but research indicates areas of potential problems.
\end{abstract}

Keywords: European Investigation Order, investigative measures, police, admissibility of evidence

\section{INTRODUCTION}

After a long period of identifying difficulties and trying to find appropriate solutions, the introduction of the EIO in 2014 accelerated and expanded European

This paper is a product of work which has been supported by Croatian Science Foundation under the project 8282 „Croatian Judicial Cooperation in Criminal Matters in the EU and the Region: Heritage of the Past and Challenges of the Future" (CoCoCrim) 
cross-border co-operation. ${ }^{1}$ The Directive was transposed into Croatian legislation in 2017, so it is possible to observe its first effects in the practice. The Act on Judicial Cooperation in Criminal Matters with Member States (AJCCM) entered into force in $2018 .^{2}$ The main advantages of this legal instrument are that it defines deadlines for investigative measures, enforces limitations for rejecting orders and it reduces bureaucratic procedures. Besides collection of evidence, this instrument also includes the transfer of evidence to the issuing country.

Despite the aforementioned advantages, criticism was focused on the EIO. Giving priority to speed could have negative impact on other aspects such as different legal proceedings in each state and admissibility of evidence in a criminal procedure. The EIO is essentially based on the principle of mutual recognition which is derived from the free market principles. Such principle was previously unknown in the area of criminal procedure law until the European Arrest Warrant (EAW) had been introduced. ${ }^{3}$

The aim of the paper is to show a brief development of the EIO, to present discussions in European scientific circles, and to perform case-study of first orders that were received in Croatian police units. Only one work on the EIO was published in Croatian periodicals so far, and it is focused on domestic provisions without analyzing background that was elaborated in foreign discussions. Part of this paper is directed on analyzing important issues that have not been covered. Case study tries to connect theoretical problems with observed effects in practice.

\section{SOME ISSUES DURING THE EIO'S DRAFTING}

\subsection{Problems of co-operation development}

If we try to recall the milestones of cross-border development in the last two decades, we can see that it has gone through several basic phases. In the first stage, only the acquisition of data that already existed in a particular legal system was possible. This concerned only access to particular records or the transfer of existing evidence. At the second stage of development, the powers were broadened so it was possible to request a new investigatory activity that had not been executed previously. The third stage of development was the introduction of additional

Directive 2014/41/EU of the European Parliament and of the Council of 3 April 2014 regarding the European Investigation Order in criminal matters, [2014] OJ L130/1, 1.5.2014, p. 1-36

2 Act on Judicial Cooperation in Criminal Matters with Member States of the European Union, Official Journal No. 91/10, 81/13, 124/13, 26/15, 102/17, 68/18

3 Council Framework Decision 2002/584/JHA of 13 June 2002 on the European arrest warrant and the surrender procedures between Member States, [2002] OJ L190/1, 18.7.2002, p. 1-20 
processing of the collected sources such as expert analysis, analytical processing and some criminalistic methods. The EIO has introduced the last two phases, which means that its contribution to the expansion of the scope is very important. The goal was to unify various approaches and types of cooperation into one legal instrument. ${ }^{4}$

The emergence of a solution that increases the number of investigative actions was not easy, because many problems have arisen in practice. There were various negative experiences with earlier instruments (e.g. order for freezing evidence - 2003).5 Such legal instrument has proved inadequate in practice. It was adopted by almost all European countries but the application was very rare. That was reason why it was changed soon, so in 2008 the European Evidence Warrant (EEW) was introduced. ${ }^{6}$ The existence of significant difficulties has shown that it took five years to complete drafting procedure. Even greater dilemmas were displayed by the fact that only two years after its adoption, a new concept has emerged. The main issue was the arrangement of general principles that would respect various legal frameworks. It is also peculiar that the EIO initiative was not initiated on behalf of the official EU bodies. Launching the legal framework for the EIO was started by few member states that revealed space to accelerate cross-border cooperation. ${ }^{7}$ It can be seen that introducing such instrument was not easy development.

\subsection{Introducing the principle of mutual recognition}

Further characteristic is that the differences in law systems have been overpowered by the principle of mutual recognition. This principle is essentially related to a trust in foreign judicial decisions. European integration has progressed significantly over the decades and such processes have invoked greater confidence in foreign justice. But the EIO has been a subject of criticism because of adopting this principle. Allegrezza considers it is difficult to predict the application of this principle, and although the principle is neutral in its action, the negative consequences could arise from variations of law systems. ${ }^{8}$

4 Mangiaracina, A., A new and controversial scenario in the gathering of evidence at the European level: the proposal for a directive on the European investigation order, Utrecht Law Review, 10, 2014, p. 113

5 Council Framework Decision 2003/577/JHA of 22 July 2003 on the execution in the European Union of orders freezing property or evidence, [2003] OJ L196/45, 2.8.2003, p. 45-55

6 Council Framework Decision 2008/978/JHA of 18 December 2008 on the European evidence warrant for the purpose of obtaining objects, documents and data for use in proceedings in criminal matters, [2008] OJ L350/72, 30. 12. 2008

7 Mangiaracina, op. cit., note 4.

8 Allegrezza, S., Collecting Criminal Evidence Across the European Union: The European Investigation Order Between Flexibility and Proportionality, in: Ruggeri, S. (ed.), Transnational Evidence and Multicultural 
One of the factors that contributed to the introduction of principle was the role model used in the European Arrest Warrant (EAW). That instrument significantly accelerated co-operation in arrests, irrespective of criticism that it is limiting fundamental rights for minor criminal offenses. According to the model, the executing country should apply procedural formalities from the issuing country, which means that they have in fact expanded the differences on another law systems rather than attempting to close them together.

The principle of mutual recognition has enhanced the cooperation, but there are a number of grounded remarks which would need to be verified in practice. The principle of trust which is essential part of the principle of mutual recognition is not considered to be justified in situations of excessive differences in law systems. ${ }^{9}$ There are too many differences in investigative procedures, data protection, equality of arms and various evidentiary rules. The rule of law is not less important than the speed of a procedure. It seems that collection and transfer of evidence using the EIO are having preference over other issues. Critics therefore refer to such rule as mutation in which national evidentiary rules are still in force, because of absence of uniform European procedural approach. ${ }^{10}$

As one of the biggest negative sides of the EIO, Schünemann considers the consequence of the transfer of free market principle into the area of criminal proceedings. ${ }^{11}$ The principle of mutual recognition has roots in economy, but criminal proceedings have quite different environment. Allegrezza finds roots of this principle in economic reasons. ${ }^{12}$ The principle of mutual recognition was created with the aim to faster exchange of products, as it ensures quick action, it does not consider differences between individual systems, and does not impose any particular limitations. Evidence is not like products that will depend on the market's preference, but there are additional values in each criminal proceeding. The goal of improving transfers of evidence from one country to another is not so important

Inquiries in Europe, Developments in EU Legislation and New Challenges for Human Rights-Oriented Criminal Investigations in Cross-border Cases, Springer, London, 2014, pp. 51-71

9 Heard, C.; Mansell, D., The European Investigation Order: changing the face of evidence-gathering in EU cross-border cases, New Journal of European Criminal Law, 2(4), 2011, pp. 353-367

10 Daniele, M., Evidence gathering in the realm of the European Investigation Order: from national rules to global principles, New Journal of European Criminal Law, 6(2), 2015, pp. 179-194

11 Schünemann, B., The European Investigation Order: A Rush into the Wrong Direction, in: Ruggeri, S. (ed.), Transnational Evidence and Multicultural Inquiries in Europe, Developments in EU Legislation and New Challenges for Human Rights-Oriented Criminal Investigations in Cross-border Cases, Springer, London, 2014, pp. 29-37

12 Allegrezza, S., Critical remarks on the Green Paper on obtaining evidence in criminal matters from one member state to another and securing its admissibility, Zeitschrift für Internationale Strafrechtsdogmatik, 5, 2010, pp. 569-579 
to have a priority ahead of legal values. Allegrezza compares it with the exchange of unsafe products. ${ }^{13}$

Neither one cross-border cooperation instrument seems to have been so much criticized in the drafting stage. Schünemann concludes that the EIO is a deviation from the applicable principles. ${ }^{14}$ The EIO drafting process was bureaucratic and non-transparent, and the flexibility in its implementation is considered to be a violation of principle of legal certainty. Allegrezza emphasizes insufficient transparency in making of the EIO Draft and problem of circumvention of empirical scientific research. ${ }^{15}$

With respect to the principle of mutual recognition, it is significant to consider new jurisprudence of the highest European courts. The judgment delivered by the European Court of Justice in joined cases Aranyosi (C-404/15) and Căldărar (C659/15) found that during the execution of the EAW it was necessary to ascertain whether there was a probability of breach of the fundamental rights in another state. If there are no guarantees of respecting fundamental rights, the EAW proceedings should be suspended, regardless of the principle of mutual recognition. If similar jurisprudence would have been imposed on the EIO, it could challenge the principle of mutual recognition. ${ }^{16}$

The EIO didn't eliminate problem arising causes, but it followed the need for increasing the cooperation. It did not unify or set minimum standards in criminal proceedings. The EIO has not introduced revolutionary changes in legislation. ${ }^{17} \mathrm{It}$ is an instrument that has brought progress in some areas, but they are not coherent in general. ${ }^{18}$ It is dangerous if, due to the lack of common standards in some legal systems, the fundamental rights in other countries could be violated.

$13 \quad$ ibid., p. 572

14 Schünemann, op. cit., note 11

15 Allegrezza, op. cit., note 12.

16 Łazowski, A., The Sky Is Not the Limit: Mutual Trust and Mutual Recognition après Aranyosi and Caldara$r u$, Croatian Yearbook of European Law and Policy, 14(14), 2018, pp. 1-30

„However, first, the Court has recognised that limitations of the principles of mutual recognition and mutual trust between Member States can be made in exceptional circumstances“, (\$ 82.). „Whenever the existence of such a risk is identified, it is then necessary that the executing judicial authority make a further assessment, specific and precise, of whether there are substantial grounds to believe that the individual concerned will be exposed to that risk because of the conditions for his detention envisaged in the issuing Member State“, Aranyosi i Căldăraru (C-404/15 i C-659/15), \$92

17 Daniele, op. cit., note 10

18 Gless, S., Transnational cooperation in criminal matters and the guarantee of a fair trial: approaches to a general principle, Utrecht Law Review, 9, 2013, p. 108 


\section{DIFFERENCES IN LEGAL SYSTEMS THAT COULD HAVE AN EFFECT ON THE EIO}

Some remarks during the EIO's adoption were that it was trying to introduce too much change too soon. ${ }^{19}$ EU does not have unified law system neither in the judiciary nor in the practice. The problem is that the countries with the most severe criminal law or weakest procedural provisions in the protection of citizen's rights, can submit an order that should be enforced in any other European country. ${ }^{20}$ The obligation of the EIO to use the law of issuing country had intention to reduce the possibility of transfer to another country with broader investigatory powers and lower protection of rights of citizens. ${ }^{21}$

Since each system achieves a delicate balance in a specific way, it is not possible to combine their remoted parts. The EIO is making a hybrid procedural law which will be very difficult to deal with, both by the prosecution and the defense. For instance, the powers of covert surveillance were left out of the Draft Directive. Hesitation on introducing the covert measures, which are considered as one of the most dangerous measures for fundamental rights, shows that there was reluctance in accepting the principle of trust in all law systems. Despite these remarks, covert measures were later adopted in a final draft of the Directive. ${ }^{22}$

Given that the EIO procedure can request various investigative measures that may not exist in some states, this could override domestic law system. A consistency test is required to find the suitable measure. Particular investigative measures may be limited to certain categories of persons or criminal offenses. Vermuelen found it naive to expect that all countries will approve required measures of the EIO, regardless of their legal system..$^{23}$ As countries could pursue to move investigation to another country in which it is easier to be implemented, perpetrators would similarly try to escape to the country where it is most difficult to gather evidence against them, ${ }^{24}$ or where they have the widest rights of defense. Our AJCCM has

19 Bachmaier, L., Mutual Recognition and Cross-Border Interception of Communications, in: Brière, C. et al. (eds.), The Needed Balances in EU Criminal Law: Past, Present and Future, Hart Studies in European Criminal Law, Bloomsbury Publishing, 2017, pp. 313-336

20 Schünemann, op. cit., note 11, p. 31

21 Zimmermann, F.; Glaser, S.; Motz, A., Mutual Recognition and its Implications for the Gathering of Evidence in Criminal Proceedings: a Critical Analysis of the Initiative for a European Investigation Order, European Criminal Law Review, 2011, pp. 56-84

22 Mangiaracina, op. cit., note 4

23 Vermeulen, G., Free gathering and movement of evidence in criminal matters in the EU: Thinking beyond borders, striving for balance, in search of coherence, Maklu, Apeldoorn, 2011, p. 33

24 Gless, op. cit., note 18 
provided possibility of refusal of the investigative order if it is opposite to our legal order (eg. Art. 42. ab).

Spencer has considered proposal of so-called standardized packages for investigative actions as one of the model that could uniform European approach. For some investigative actions, the minimum procedural guarantees must be fulfilled. ${ }^{25}$ The imposition of such rules could gradually lead to the equalization of criminal investigation and other investigatory actions.

For intrusive forms of criminal investigation that have a number of material and procedural conditions, violation of any provision will lead to exclusion of evidence. Due to possible major differences, the AJCCM stipulates that covert investigative actions will have to be approved according to our legal order (decision of investigating judge according to the CPA) ${ }^{26}$ In Croatian law, evidence will be illegal if a judge has not explained reasons for issuing a warrant for covert measures. It makes no difference if covert actions were substantially founded. Similar situation is with procedural formalities in investigatory measures such as home search or interrogation of suspect. For example, if interrogation is not videotaped, it will be considered illegal without considering if statements were voluntary, and the rule of fruits of poisonous tree applies too. There are forty-five provisions in the CPA whose violations will automatically lead to the illegality of evidence, and there could be some more if constitutional rules could be directly applied.

As a part of the solution for different legal arrangements, some consider appropriate to use the standards adopted by the European Court of Human Rights (ECtHR) jurisprudence. The position of the ECtHR as a basic assimilation element is often presented in the elaboration of the problems encountered by the EIO. According to some viewpoints, this is the only model that can promote certain rights. ${ }^{27}$ Such expectations are unrealistic. Allegrezza justifiably suggests that the role of ECtHR can only be an abstract role because it does not have wide authority in the EU. ${ }^{28}$ The role of the Court is primarily in other aims and it can not be a key supporter of harmonization of cross-border cooperation.

Usage of collected materials in criminal procedure is not governed by the EIO although this is the main long-term purpose of the evidence gathering procedure.

25 Spencer, J. R., The Green Paper on obtaining evidence from one member state to another and securing its admissibility: the reaction of one British lawyer, Zeitschrift fur Internationale Strafrechtsdogmatik, 9, 2010, pp. 605

26 Criminal Procedure Act, Official Journal No. 152/08, 76/09, 80/11, 121/11, 91/12, 143/12, 56/13, $145 / 13,152 / 14,70 / 17$

27 Gless, op. cit., note 18 , p. 103

28 Allegrezza, op. cit., note 12 
Due to differences in gathering procedures, there are situations where significant problems may arise in the admissibility of evidence. If the investigatory action is determined by the law of one country, executed under provisions of another country after which evidence is returned to the foregoing, complex situations may arise. The EIO does not deal with the use of its results, especially if more countries are involved and evidence is not repeatable. ${ }^{29}$ This area is one of the most problematic that could occur as a consequence of the EIO. ${ }^{30}$ Because of positive intentions in the area of enhancing speed and widening scope of the investigative actions, main problem could have been relocated to the area of admissibility. In Croatian law system, real evidence can also be excluded if some procedural provisions were not followed, unlike many European systems.

Complex interpretations on admissibility of evidence were present in Croatian legislation. Examples of interpretation of provisions on a vehicle search, rules on presence of two witnesses during a home search, rules on interception of text messages and similar legal issues have come up with inconsistent case-law during last decades. ${ }^{31}$ If there are problems with interpreting rules that originates from our own legal system, then we can expect it will be more difficult to interpret foreign rules. ${ }^{32}$

\section{ANALYSIS OF THE FIRST EIO'S IN 2018}

\subsection{General data}

For the purpose of this research, a case study on the small EIO sample was performed. The analysis presented herein is a part of wider scientific project aimed at identifying features in the application of this instrument and the problems that have arisen. At this preliminary stage of the project, due to a small number of investigation orders and early stage of the criminal proceedings, there are no extensive data. Therefore, this analysis can present only insight in the first effects of the new cooperation tool, but it can suggest some potential issues for the future. The EIO's sample collected from the authorities of the General Police Directorate in 2018 includes only five investigation orders. Police is a body which is most often conducting investigative actions in Croatia, nevertheless that other authori-

29 Ouwerkerk, J. W., Quid Pro Quo? A comparative law perspective on the mutual recognition of judicial decisions in criminal matters, Cambridge, Intersentia, 2011, p. 278

30 Kusak, M., Common EU minimum standards for enhancing mutual admissibility of evidence gathered in criminal matters, European Journal on Criminal Policy and Research, 23(3), 2017, pp. 337-352

31 Karas, Ž., Illegal Police Evidence, Laserplus, Zagreb, 2006

32 Karas, Ž., Inconsistent Case Law in Criminal Procedure as a Violation of the European Convention on Human Rights, Collected Papers of Zagreb Law Faculty, 64 (1), 2014, pp. 111-131 
ties are also involved in the EIO proceedings. There are some other investigative orders that are in the scope of the public prosecutor's office. Cases in police work are more complex and they need a variety of other measures that are not available to other authorities in Croatia.

The orders were sent to Croatia from various European countries (Germany, France, and Netherlands) and two EIO's from Italy. Such small number of orders indicates that this co-operation instrument was very rarely used by police in the first months of its application. In almost all investigation orders received, urgent procedure was required. The reason for the urgency was related to the danger of concealment of evidence, or because there was a need to arrest all participants in several countries simultaneously.

Concerning investigative measures that were required, three investigative orders requested only one investigative measure, one order required four investigative actions, and one order required seven different investigative measures. Observing the type of investigative measures, three orders mainly dealt with police powers from the Police Powers and Duties Act (PPDA), ${ }^{33}$ and two orders required different evidentiary actions from the CPA.

In three covered cases, issued EIO's are based on a prior court's decision in issuing country. There wasn't any opposite decision delivered by Croatian courts, which means that the rules which are governing the principle of mutual recognition were not an issue in covered cases. The criminal offenses are from various domains of smuggling of immigrants, drugs and arms trafficking, and pornographic materials of minors. All offenses are also enlisted in the Croatian criminal law so there weren't any issues in that field.

\subsection{Types of investigative measures}

Ambiguities may arise because of a definition of the investigative measures required by some investigation orders. In two investigation orders, secret surveillance of suspects was requested. It was not entirely clear whether short-term monitoring can be carried out as a covert police power, or a long-term surveillance was needed. It could fall under the definition of special evidence measures but then it would require a particular legal procedure according to Art. 332 of the CPA. The assessment depends on the level of restriction of privacy in Croatian law. A long-term monitoring is revealing a lot of private data and it can not be defined as covert police measure (Art. 80, para. 2 of the PPDA) that doesn't need a warrant.

33 Police Powers and Duties Act, Official Journal No. 76/09, 92/14 
In our jurisprudence, there were a variety of benchmarks in determining whether some measures could be defined as a special evidence action that needed a court warrant,$^{34}$ and it is apparent that similar criteria should be used for cross-border cooperation too. Effects of this interpretation should be visible in later stages of procedure. Such issues could emphasize differences in definitions of certain investigatory measures elaborated earlier.

In the case of covert measures, in accordance with our legal regulation, a special approval of the investigating judge is needed (Art. 42.am para. 2 of the AJCCM). In order to prepare such approval, it is necessary for police to present more evidence to the court, rather than short summary in the EIO. The court approval should be the same as for domestic citizens, because it would otherwise reduce the protection and risk inadmissibility of evidence. The Croatian law system has many provisions governing covert measures that are stricter than many rules in comparative law.

In one of the covered cases, an investigative measure of the home search was requested. That order required compliance with some specific procedural formalities of issuing country. Given that France was issuing state, it was necessary to use two suspect's relatives during the search. Such rule is rare in comparative law since some European states prescribe the obligation to remove all other persons from the search site in order to preserve the privacy. However, that rule was not an issue in Croatian law because presence of two witnesses during the home search is an obligatory provision. Furthermore, if two witnesses were separated during the home search in different rooms, all gathered evidence will be illegal, despite there wasn't any remark on the reliability of gathered evidence. Irrespective that one witness confirms there is nothing suspicious in discovering that particular evidence, it must be excluded according to our exclusionary rule. This feature emphasizes differences and potential problems in the field of admissibility as stated above.

The interpretation of this rule has been cause of many problems in Croatian law (Art. 246 CPA). Such French provision would not have caused difficulties, but some difficulties could arise if the EIO came from a different law system that would forbid the presence of two witnesses during the home search, or if a suspect would consider that his privacy could be undermined by a witness presence. The Croatian statutory provisions stipulate that the EIO will be performed in accordance with domestic legal regulations (Art. 42.h para. 1 AJCCM). If a home search reveals evidence of some other criminal offense, it would be inadmissible if the compulsory provisions of the CPA were not respected. It seems that the execu-

$34 \quad$ Karas, op. cit., note 32 
tion of the EIO would require a thorough knowledge of comparative law and all involved consequences.

Looking at additional procedural formalities, in one EIO it was requested that two certified investigators should participate in interrogation that was related to sexual crimes. Similar rule exists in our law system too, so there was not any obstacle detected.

\subsection{Suspects discovered by issuing country}

If we look at the characteristics of the citizenship of the persons that were subjected to investigative measures, in the most cases foreign nationals were involved in the commission of offenses. Offenses were perpetrated outside the territory of Croatia. Only some minor part of the criminal activities was executed in Croatia, or some evidence could be found here. There were no double criminality issues in this analysis.

There is only one case in which suspects were nationals of Croatia. In that criminal case, information was gathered on the smuggling of weapons and narcotics from Croatia to another European country. Given that the investigating authorities of that foreign country discovered preparatory activities, they started covert measures and collected data that requested similar actions on the territory of Croatia. During the start of investigation, the Croatian authorities were not familiar with a fact that mentioned suspects intend to commit any criminal offenses. It follows that a significant initiative may be instigated by a foreign country using the EIO.

In this respect, the EIO may indirectly stimulate some criminal investigations that certain states may not have started by themselves. If there is a lack of interest in investigating certain criminal acts, other country can use the EIO as some kind of warning signal for domestic authorities. This consequence could be particularly sensitive if some other crimes would be investigated, such as political corruption or some offenses connected with political figures.

\subsection{Sources of discovery}

Most of the criminal offenses were detected by some covert measures executed by foreign countries (communication surveillance, confidential sources, informants etc.). Some of these covert sources (informants) could eventually originate from executing country too, but this is not described as measure in the EIO. Sometimes it should be presented on which reliable sources certain facts are founded in a court warrant. This could provoke procedures for questioning reliability of par- 
ticular covert sources, but that procedure isn't governed by the EIO. This is one of potential issues that may arise in future practice.

For all criminal offenses, the foreign police units have already collected suspect's personal data and other detailed information. There have not been sought investigative actions aimed on establishing the identity of suspect. Only actions at the final stages prior to arrests were asked from Croatia.

\section{CONCLUSION}

From the remarks that were emphasized during the EIO's adoption, we can see that many aspects of this instrument were problematized in theory, but negative consequences were not shown in practice so far. During the EIO's enactment, many foreign scientific papers expressed serious remarks on various aspects of the instrument. The purpose of the research in this paper was to examine some of those problems and to analyze if they had already manifested in practice. Preliminary results indicate some vulnerable fields, but further research should be performed on a wider sample to gain a complete insight.

In the analysis, there were no issues revealed concerning provisions regulating the principle of mutual recognition, double criminality or admissibility of evidence. That is a consequence of procedural similarity between Croatia and few issuing countries, but there should be considered that covered sample is too small to reach broader conclusions. The analysis is not indicating that our law system is being used to avoid some procedural provisions of issuing country. The case study indicates that particular investigatory measures (eg. home search, covert measures, interrogation of suspect) are governed by provisions different from other countries, and it will be interesting to analyze such situations in the future.

There could emerge some difficulties in definitions of some covert investigatory measures or during the execution of some procedural formalities. The definition of covert measures depends on their duration, the intensity of the fundamental rights constraint and the application methods. Such features may differ between countries. A court warrant for covert measures must have a detailed explanation, what could be impossible without receiving more detailed data from the issuing country. In some cases, there will be a need to check a reliability of covert sources used for intrusive measures approval. That could be difficult if foreign informants were used. Results suggest that the EIO could be used as indirect encouragement if an executing state was not familiar with organized criminal activities that originate from its' territories. 
Results of analysis of the first investigative orders submitted to Croatian police in 2018 can suggest in which fields there could appear problems in the future. All consequences are not yet apparent because of the short term of application. Therefore, subsequent stages of this project during 2019 and 2020 will be focused on a wider sample, and on investigation orders issued by Croatian authorities.

\section{REFERENCES}

\section{BOOKS AND ARTICLES}

1. Allegrezza, S., Critical remarks on the Green Paper on obtaining evidence in criminal matters from one member state to another and securing its admissibility, Zeitschrift für Internationale Strafrechtsdogmatik, 5, 2010, pp. 569-579

2. Allegrezza, S., Collecting Criminal Evidence Across the European Union: The European Investigation Order Between Flexibility and Proportionality, in: Ruggeri, S. (ed.), Transnational Evidence and Multicultural Inquiries in Europe, Developments in EU Legislation and New Challenges for Human Rights-Oriented Criminal Investigations in Cross-border Cases, Springer, London, 2014, pp. 51-71

3. Arasi, S., The EIO Proposal and the Rules on Interception of Telecommunications, in: Ruggeri, S. (ed.), Transnational Evidence and Multicultural Inquiries in Europe, Developments in EU Legislation and New Challenges for Human Rights-Oriented Criminal Investigations in Cross-border Cases, Springer, London, 2014, pp. 127-139

4. Bachmaier, L., Mutual Recognition and Cross-Border Interception of Communications, in: Brière, C. et al. (eds.), The Needed Balances in EU Criminal Law: Past, Present and Future, Hart Studies in European Criminal Law, Bloomsbury Publishing, 2017, pp. 313-336

5. Belfiore, R., Critical Remarks on the Proposal for a European Investigation Order and Some Considerations on the Issue of Mutual Admissibility of Evidence, in: Ruggeri, S. (ed.), Transnational Evidence and Multicultural Inquiries in Europe, Developments in EU Legislation and New Challenges for Human Rights-Oriented Criminal Investigations in Cross-border Cases, Springer, London, 2014, pp. 91-104

6. Crnčec, I.; Mišerda, T., Novela Zakona o pravosudnoj suradnji u kaznenim stvarima s državama članicama Europske unije, Hrvatski ljetopis za kaznene znanosti i praksu, 24(2), 2017, pp. $525-551$

7. Daniele, M., Evidence gathering in the realm of the European Investigation Order: from national rules to global principles, New Journal of European Criminal Law, 6(2), 2015, pp. 179-194

8. Foti, D., European Investigation Orders and Non-repeatability of Evidence in Cross-Border Cases: The Italian Perspective, in: Ruggeri, S. (ed.), Transnational Evidence and Multicultural Inquiries in Europe, Developments in EU Legislation and New Challenges for Human Rights-Oriented Criminal Investigations in Cross-border Cases, Springer, London, 2014, pp. 29-37

9. Gless, S., Transnational cooperation in criminal matters and the guarantee of a fair trial: approaches to a general principle, Utrecht Law Review, 9, 2013, p. 90 
10. Gless, S.; Vervaele, J. A., Law should govern: aspiring general principles for transnational criminal justice, Utrecht Law Review, 9, 2013, p. 1

11. Heard, C.; Mansell, D., The European Investigation Order: changing the face of evidencegathering in EU cross-border cases, New Journal of European Criminal Law, 2(4), 2011, pp. 353-367

12. Hržina, D., Novela Zakona o pravosudnoj suradnji u kaznenim stvarima s državama članicama Europske unije, Pravosudna akademija, Zagreb, 2018

13. Karas, Ž., Inconsistent Case Law in Criminal Procedure as a Violation of the European Convention on Human Rights, Collected Papers of Zagreb Law Faculty, 64 (1), 2014, pp. 111-131

14. Karas, Ž., Some Objections on the Theories on Exclusion of Unlawfully Obtained Real Evidence, Police and Security, 21(4), 2013, pp. $753-773$ (in Croatian)

15. Karas, Ž., Illegal Police Evidence, Laserplus, Zagreb, 2006 (in Croatian)

16. Kusak, M., Common EU minimum standards for enhancing mutual admissibility of evidence gathered in criminal matters, European Journal on Criminal Policy and Research, 23(3), 2017, pp. 337-352 (in Croatian)

17. Łazowski, A., The Sky Is Not the Limit: Mutual Trust and Mutual Recognition après Aranyosi and Caldararu, Croatian Yearbook of European Law and Policy, 14(14), 2018, pp. 1-30

18. Maggio, P., The EIO Proposal for a Directive and Mafia Trials: Striving for Balance Between Efficiency and Procedural Guarantees, in: Ruggeri, S. (ed.), Transnational Evidence and Multicultural Inquiries in Europe, Developments in EU Legislation and New Challenges for Human Rights-Oriented Criminal Investigations in Cross-border Cases, Springer, London, 2014, pp. 139-151

19. Mangiaracina, A., A new and controversial scenario in the gathering of evidence at the European level: the proposal for a directive on the European investigation order, Utrecht Law Review, 10, 2014, p. 113

20. Ouwerkerk, J. W., Quid Pro Quo? A comparative law perspective on the mutual recognition of judicial decisions in criminal matters, Cambridge, Intersentia, 2011

21. Pejaković Đipić, S., Fundamentals of International Police Cooperation (to be published) Police College, Zagreb, 2019 (in Croatian)

22. Rafaraci, T., The right of defence in EU judicial cooperation in criminal matters, in: Transnational Inquiries and the Protection of Fundamental Rights in Criminal Proceedings, Springer, Berlin, 2013, pp. 331-343

23. Ruggeri, S., Transnational Evidence and Multicultural Inquiries in Europe, Developments in EU Legislation and New Challenges for Human Rights-Oriented Criminal Investigations in Cross-border Cases, Springer, London, 2014

24. Sawyers, D., The European Investigation Order, Travelling without a Roadmap, CEPS, Brussels, 2011

25. Schunemann, B., The European Investigation Order: A Rush into the Wrong Direction, in: Ruggeri, S., Transnational Evidence and Multicultural Inquiries in Europe, Developments in EU Legislation and New Challenges for Human Rights-Oriented Criminal Investigations in Cross-border Cases, Springer, London, 2014, pp. 29-37 
26. Spencer, J. R., The Green Paper on obtaining evidence from one member state to another and securing its admissibility: the reaction of one British lawyer, Zeitschrift fur Internationale Strafrechtsdogmatik, 9, 2010, pp. 602-606

27. Vermeulen, G., Free gathering and movement of evidence in criminal matters in the EU: Thinking beyond borders, striving for balance, in search of coherence, Maklu, Apeldoorn, 2011

28. Vogler, R., The European Investigation Order: Fundamental Rights at Risk?, in: Ruggeri, S. (ed.), Transnational Evidence and Multicultural Inquiries in Europe, Developments in EU Legislation and New Challenges for Human Rights-Oriented Criminal Investigations in Cross-border Cases, Springer, London, 2014, pp. 45-49

29. Winter, B. L., European investigation order for obtaining evidence in the criminal proceedings, Zeitschrift für Internationale Strafrechtsdogmatik, 9, 2010, pp. 580-589

30. Zimmermann, F.; Glaser, S.; Motz, A., Mutual Recognition and its Implications for the Gathering of Evidence in Criminal Proceedings: a Critical Analysis of the Initiative for a European Investigation Order, European Criminal Law Review, 2011, pp. 56-84

\section{COURT OF JUSTICE OF THE EUROPEAN UNION}

1. Joined Cases C-404/15 and C-659/15 PPU, v Generalstaatsanwaltschaft Bremen [2016] ECLI:EU:C:2016:198, 05.04.2016

\section{EU LAW}

1. Directive 2014/41/EU of the European Parliament and of the Council of 3 April 2014 regarding the European Investigation Order in criminal matters, [2014] OJ L130/1, 1.5.2014, p. 1-36

2. Council Framework Decision 2002/584/JHA of 13 June 2002 on the European arrest warrant and the surrender procedures between Member States, [2002] OJ L190/1, 18.7.2002, p. 1-20

3. Council Framework Decision 2003/577/JHA of 22 July 2003 on the execution in the European Union of orders freezing property or evidence, [2003] OJ L196/45, 2.8.2003, p. 45-55

4. Council Framework Decision 2008/978/JHA of 18 December 2008 on the European evidence warrant for the purpose of obtaining objects, documents and data for use in proceedings in criminal matters, [2008] OJ L350/72, 30. 12. 2008

\section{LIST OF NATIONAL REGULATIONS, ACTS AND COURT DECISIONS}

1. Act on Judicial Cooperation in Criminal Matters with Member States of the European Union, Official Journal No. 91/10, 81/13, 124/13, 26/15, 102/17, 68/18

2. Criminal Procedure Act, Official Journal No. 152/08, 76/09, 80/11, 121/11, 91/12, $143 / 12,56 / 13,145 / 13,152 / 14,70 / 17$

3. Police Powers and Duties Act, Official Journal No. 76/09, 92/14 